\title{
MAKE A MATCH DALAM PEMBELAJARAN WRITING DI KELAS V SEKOLAH DASAR
}

\author{
BUDI FEBRIYANTO \\ Dosen Program Studi PGSD Universitas Majalengka \\ budi_febry88@yahoo.co.id
}

\begin{abstract}
Abstrak
Salah satu tujuan penting dalam pembelajaran bahasa Inggris di sekolah dasar adalah menumbuhkan minat anak dalam belajar bahasa Inggris. Pembelajaran bahasa Inggris terintegrasi dalam empat keterampilan berbahasa yaitu listening, speaking, reading, dan writing. Diantara empat keterampilan berbahasa tersebut, writing merupakan keterampilan yang cukup kompleks. Pembelajaran writing di sekolah dasar haruslah disajikan semenarik mungkin agar siswa tidak merasa bosan. Maka dari itu dibutuhkan kemampuan guru untuk dapat menyajikan paket pembelajaran yang menarik dan bermakna. Oleh karena itu peneliti melakukan penelitian dengan menggunakan salah satu teknik pembelajaran kooperatif yaitu make a match agar dapat menyajikan pembelajaran yang menarik dan tidak membosankan bagi siswa serta mampu membantu siswa dalam meningkatkan keterampilan writingnya.Tujuan dari penelitian ini adalah untuk mengetahui proses dan hasil belajar siswa kelas V SD dalam pembelajaran writing dengan menggunakan make a match. Penelitian tindakan kelas pada siswa kelas V dilakukan di SD Negeri Cikoneng, Kecamatan Cileunyi Kabupaten Bandung. Instrumen yang digunakan dalam penelitian ini adalah lembar observasi, lembar wawancara, catatan lapangan, worksheet, lembar evaluasi dan dokumentasi. Data diperoleh, dianalisis dan direfleksi dengan menggunakan metode deskripsi kualitatif. Dapat ditarik kesimpulan bahwa penggunaanmake a match pada pembelajaran writing telah memperlihatkan perubahan hasil belajar pada setiap siklusnya.Berdasarkan hasil penelitian yang dilakukan peneliti melaporkan hasil secara keseluruhan siklus dan tindakan yang didasarkan atas penilaian proses dan hasil yang diperoleh pada siswa dengan nilai individu pada siklus I memperoleh nilai sebagai berikut: Hasil belajar siswa dalam pembelajaran writing di kelas V SD dengan menggunakan make a match sudah cukup baik, karena nilai rata-rata hasil belajar siswa sudah mencapai 57,5. Sedangkan pada siklus II hasil pembelajaran siswa mengalami peningkatan. Hal ini dibuktikan dengan nilai rata-rata hasil belajar siswa mencapai 63,6, dan pada siklus III hasil belajar siswa mengalami peningkatan dengan nilai rata-rata hasil belajar siswa mencapai 77,2. Dengan demikian penggunaan make a match dalam pembelajaran writing dapat meningkatkan kemampuan writing siswa. Oleh karena itu peneliti merekomendasikan bagi guru menggunakan make a match dalam pembelajaran writing dengan memperhatikan pengelolaan kelas sehingga mendapatkan hasil pembelajaran yang optimal.
\end{abstract}

Kata Kunci: Cooperative Learning, Make A Match, Pembelajaran Writing 


\section{Pendahuluan}

Dalam era informasi dan globalisasi saat ini, pemerintah menyadari pentingnya peran bahasa Inggris dan sumber daya manusia yang memiliki keandalan berkomunikasi dalam bahasa Inggris, yang di Indonesia merupakan bahasa asing. Bahasa Inggris merupakan pembelajaran yang mengajarkan konsep baru bagi anak dalam memahami bahasa baru (foreign language) yang disesuaikan dengan kehidupan sehari-hari anak. Pembelajaran bahasa Inggris pada jenjang pendidikan dasar identik dengan mengajari seorang bayi bahasa ibu. Dimana secara umum anak-anak di sekolah dasar belum mengenal bahasa Inggris. Sehingga hal itu akan berdampak pada pola pengajaran bahasa Inggris yang lebih bersifat pengenalan. Pembelajaran bahasa Inggris di sekolah dasar disampaikan sesuai dengan perkembangan serta karakteristik siswa sekolah dasar, yaitu ditinjau dari tingkat perkembangan intelektual, fisik, serta tingkat perkembangan bahasanya. Pembelajaran Bahasa Inggris terintegrasi dalam empat keterampilan berbahasa yaituListening, Speaking, Reading dan Writing. Diantara empat keterampilan berbahasa tersebut, writing adalah salah satu keterampilan yang cukup kompleks. Writing skill diajarkan dengan tujuan agar siswa mempunyai kemampuan dalam menuangkan ide, gagasan, pikiran, pengalaman, dan pendapatnya dengan benar. Salah satu faktor penting dalam keberhasilan pembelajaran bahasa Inggris di sekolah dasar adalah guru yang mengajarkan bahasa Inggris. Guru EYL merupakan faktor yang penting, sebab ia memperkenalkan kepada siswa bahwa ada bahasa lain, selain bahasa ibu dan bahasa Indonesia. Dalam hal ini, tugas guru EYL cukup berat. Guru inilah yang mengajarkan bahasa Inggris sebagai langkah awal dan meletakkan dasar, baik secara akademis maupun psikologis. Pemilihan metode atau teknik mengajar yang menarik dan sesuai dengan usia dan karakteristik pebelajar muda tidak menjamin keberhasilan pengajaran bahasa Inggris jika guru kurang mumpuni dalam melaksanakan kegiatan. Ada banyak faktor yang membuat pembelajaran bahasa Inggris terutama materi writing tidak berjalan dengan optimal. Salah satu faktor kurang berhasilnya pembelajaran tersebut adalah cara belajar yang konvensional. Kemampuan guru dalam menampilkan proses kegiatan belajar yang efektif, kreatif, inovatif, dan menyenangkan belum dapat dilaksanakan dengan baik.

\section{Hakikat Peserta Didik}

Peserta didik memiliki karakteristik yang harus dipahami oleh para pendidik di dalam proses menuju kedewasaannya. Tirtarahardja (Sadulloh, dkk, 2007: 110) mengemukakan empat karakteristik peserta didik yaitu 1) Individu yang memiliki potensi fisik dan psikis yang khas sehingga merupakan makhluk yang unik, 2) Individu yang sedang berkembang, 3) Individu yang membutuhkan bimbingan individual dan perlakuan manusiawi, 4) Individu yang memiliki kemampuan untuk mandiri.Karakteristik anak di usia SD perlu diketahui para guru, agar lebih mengetahui keadaan peserta didik khususnya ditingkat anak usia sekolah dasar. Sebagai guru harus bisa menerapkan metode pengajaran yang sesuai dengan keadaan siswa maka sangatlah penting bagi seorang pendidik mengetahui karakteristik siswanya. Selain karakteristik yang perlu diperhatikan yaitu kebutuhan peserta didik. Setiap individu memiliki ciri dan sifat atau karakteristik bawaan dan karakteristik yang diperoleh dari pengaruh lingkungan. Karakteristik bawaan merupakan karakteristik keturunan yang dimiliki sejak lahir. Seorang anak mungkin memulai pendidikan formalnya di tingkat taman kanak-kanak pada usia 4 atau 5 tahun. Pada awal ia memasuki sekolah mungkin tertunda sampai usia 5 atau 6 tahun. Tanpa mempedulikan berapa 
umur seorang anak, karakterisik pribadi dan kebiasaan-kebiasaan yang dibawanya ke sekolah akhirnya terbentuk oleh pengaruh penting terhadap keberhasilannya di sekolah dan masa perkembangan hidupnya di masa yang akan datang.

\section{Hakikat Writing}

Writing merupakan salah satu dari empat keterampilan berbahasa selain listening, speaking, dan reading. Dalam empat keterampilan berbahasa, writing merupakan upaya dalam pengembangan bahasa tulis, disamping adanya kemampuan bahasa lisan. Bahasa tulis merupakan bentuk komunikasi tidak langsung antara penulis dan pembaca. Sokolik mengemukakan bahwa 'Writing is a combination of process and product'. Sedangkan Olson berpendapat bahwa 'The concept that writing is a process is very useful to young writers'(Linse,2005: 98).Kedua pendapat tersebut bermakna bahwa konsep menulis adalah proses yang bermakna bagi penulis muda dan merupakan perpaduan antara proses dan hasil.Byrne (1995: 1) mengatakan bahwa "Writing can be said to be act of forming these symbols: making marks on flat surface of some kind".Maksud dari pernyataan tersebut adalah bahwa writing merupakan menuangkan simbol-simbol pada suatu permukaan. Selanjutnya Byrne (1995: 1) mengemukakan "The symbols have to be arranged, according to certain convention to form words and words have to be arranged to form sentences..." Simbol-simbol ini harus disusun menjadi kata-kata, dan kata-kata menjadi kalimat. Kegiatan writing bukan hanya sekedar menggoreskan tinta tetapi memerlukan proses yang di dalamnya tentunya terdapat langkah-langkahnya. Sebagai sebuah ragam komunikasi, Yunus, dkk (2009: 1.3) mengemukakan bahwa dalam menulis setidaknya terdapat empat unsur yang terlibat yaitu: 1) Penulis sebagai penyampai pesan, 2) Pesan atau sesuatu yang disampaikan penulis, 3) Saluran atau medium berupa lambanglambang bahasa tulis seperti huruf dan tanda baca, dan 4) Penerima pesan, yaitu pembaca, sebagai penerima pesan yang disampaikan oleh penulis. Dengan demikian, dalam kegiatan menulis unsur yang terlibat didalamnya diantaranya penulis sebagai penyampai pesan, pesan itu sendiri yang memilki maksud dan tujuan, adanya medium atau perantara yang merupakan lambing-lambang bahasa tulis serta penerima pesan yang merupakan sasaran dari maksud dan tujuan tulisan tersebut.

Brewster (2002: 117) mengatakan mengenai aktivitas writing yang mengatakan bahwa terdapat dua aktivitas kegiatan writing yaitu learning to write dan write to learn. Learn to write bertujuan untuk mengajarkan ejaan (spelling), tanda baca (punctuation), dan struktur kalimat (grammar) sedangkan write to learn justru bertujuan untuk mengembangkan kreativitas menulis. Menurut Tarigan (1994: 23-24), yang dimaksud dengan maksud atau tujuan penulis (the writer's intention) adalah respon atau jawaban yang akan diperolehnya dari pembaca. Maka dapat dikatakan bahwa tujuan menulis yaitu sebagai sumber informasi bagi pembaca,dan dapat merupakan suatu desakan atau ajakan, hiburan serta sarana mengekspresikan perasaaan dan juga sebagai tujuan pemecahan masalah. Menulis sangat besar manfaatnya baik bagi diri kita sendiri maupun bagi orang lain yaitu pembaca. Dengan menulis seseorang dapat menyampaikan pesan melalui tulisan dalam bentuk ekspresi yang bermacam-macam. Keterampilan menulis merupakan kelanjutan dari kegiatan terdahulu, yaitu listening, speaking, dan reading. kegiatan menulis hendaknya disesuaikan dengan usia dan tingkat kemampuan siswa dalam menggunakan bahasa Inggris. Menurut Suyanto (2010: 26-27), menulis bisa 
dibedakan dalam dua kategori yaitu menyalin kata, kalimat, atau wacana pendek dan menulis menuntut kreativitas siswa sebaiknya diterapkan pada siswa dikelas lebih tinggi. Tujuannya untuk melatih siswa menulis dan mengeja, memakai tanda baca, dan mengenal kosakata baru serta struktur kalimat.

Pembelajaran pola bahasa yang diintegrasikan melalui tiga kegiatan terdahulu (listening, speaking, dan reading) bisa untuk mengetahui apakah anak-anak sudah menguasai bahasa Inggris melalui kegiatan menulis. Dalam pelaksanaannya tidak mungkin masingmasing pembelajaran keterampilan berbahasa ini dilakukan secara terkotakkotak. Siswa menyimak sesuatu kemudian dia bertanya atau menjawab (speaking) secara lisan atau dapat pula menulis jawaban untuk pertanyaan guru. Kegiatan belajar bahasa merupakan kegiatan terpadu yang dikemas oleh guru dengan baik. Kegiatan guru English Young Learners (EYL) lebih banyak kegiatan yang berupa mengembangkan keterampilan berbahasa yang disesuaikan dengan tujuan pembelajaran. Keterampilan berbahasa dapat disajikan secara terpadu. Kegiatan seperti listening dipadukan dengan speaking diikuti oleh reading kalau siswa diminta untuk membaca. Hal tersebut dapat diteruskan dengan kegiatankegiatan lain seperti writing, yaitu siswa diminta membuat ringkasan atau menjawab pertanyaan-pertanyaan. Sama halnya dengan keterampilan berbahasa yang lainnya (listening, speaking dan reading), keterampilan menulis juga diajarkan secara bertahap. Dalam kegiatan menulis dilakukan mulai dari kegiatan yang sangat sederhana dan dilanjutkan kedalam bentuk kegiatan yang lebih kompleks sesuai dengan perkembangan kemampuan dan keterampilan berbahasa siswa. Menurut Suyanto (2010: 69), "Kegiatan menulis secara umum dapat dibedakan menjadi empat, yaitu copying, guided writing, substituting, dan free writing". Pelaksanaan keempat macam kegiatan menulis ini tentunya perlu disesuaikan dengan tingkat kelas dan perkembangan bahasa Inggris siswa. Selain itu, yang juga perlu dipertimbangkan adalah pilihan kata, kerumitan tata bahasa yang disesuaikan dengan tingkat kesulitan bahasa Inggris yang sudah dipelajari oleh siswa.

\section{Cooperative Learning}

Kerja sama merupakan hal yang sangat penting dalam kehidupan karena kerja sama sudah menjadi kebutuhan bagi kelangsungan hidup. Cooperatif learning atau pembelajaran kooperatif adalah salah satu bentuk pembelajaran yang berdasarkan pada kegiatan kerja sama, dimana sejumlah siswa sebagai anggota kelompok menyelesaikan tugas kelompoknya secara bersama dan saling membantu satu sama lain untuk memahami suatu materi pelajaran.

Menurut Slavin, 'Cooperative learning adalah suatu model pembelajaran dimana siswa belajar dan bekerja dalam kelompok-kelompok kecil secara kolaboratif yang anggotanya 4-6 orang dengan struktur kelompok heterogen'. Sedangkan Sunal dan Hans mengemukakan 'Cooperative learning merupakan suatu cara pendekatan atau serangkaian strategi yang khusus dirancang untuk memberi dorongan kepada peserta didik agar bekerja sama selama proses pembelajaran'. Selanjutnya Stahl menyatakan 'Cooperative learning dapat meningkatkan belajar siswa lebih baik dan meningkatkan sikap tolong menolong dalam perilaku sosial' (Isjoni, 2000: 12). Berdasarkan beberapa pendapat diatas, dapat diambil kesimpulan bahwa pembelajaran kooperatif menuntut siswa untuk bekerja dalam kelompok-kelompok kecil untuk menyelesaikan tugasnya serta memupuk rasa tolong menolong antara sesama anggota. Dalam cooperative learning, peran tiap individu mempengaruhi hasil kerja secara 
keseluruhan karena dalam kelompok tersebut dituntut adanya rasa saling menghargai antar sesama anggota kelompok untuk mencapai hasil yang optimal. Roger dan David Johnson, mengatakan bahwa tidak semua kerja kelompok bisa dianggap cooperative learning. Untuk mencapai hasil yang maksimal, lima unsur model pembelajaran gotong royong harus diterapkan yaitu: 1) saling ketergantungan, 2) Tanggungjawab perseorangan, 3) tatap muka, 4) komunikasi antar anggota, dan 5) evaluasi proses kelompok. Tiga konsep sentral yang menjadi karakteristik cooperative learning sebagaimana dikemukakan Slavin (Isjoni, 2000: 21), yaitu "Penghargaan kelompok, pertanggungjawaban individu, dan kesempatan yang sama untuk berhasil". Menurut Ibrahim et al., pada dasarnya model cooperative learning dikembangkan untuk mencapai setidaktidaknya tiga tujuan pembelajaran penting yaitu: 1) Hasil belajar akademik, 2) Penerimaan terhadap perbedaan individu dan 3) Pengembangan keterampilan sosial. Menurut Sutardi dan Sudirjo (2007: 72), model pembelajaran kooperatif terdiri dari enam langkah utama atau enam tahapan sebagai berikut:

Tahap pertama, dimulai oleh guru kelas menyampaikan tujuan pembelajaran dan memotivasi siswa untuk belajar. Tahap kedua, menyajikan informasi, seringkali dengan bahan bacaan atau guru melakukan demonstrasi. Tahap ketiga, mengorganisasikan siswa ke dalam kelompok-kelompok belajar. Tahap keempat, membimbing kelompok bekerja dan belajar. Tahap kelima, melakukan evaluasi. Tahap terakhir, memberikan penghargaan. Guru memberikan penghargaan terhadap usaha-usaha kelompok atau usaha individu yang berada dalam kelompok.

Dalam pengelolaan kelas pembelajaran kooperatif, menurut Lie (2010: 38-39) harus memperhatikan tiga hal penting, yakni "pengelompokkan, semangat cooperative learning, dan penataan ruang kelas". Pengelompokkan kemacamragaman (heterogenitas) merupakan ciri-ciri yang cukup menonjol dalam pembelajaran kooperatif. Kelompok heterogenitas dapat dibentuk dengan memperhatikan berbagai macam aspek diantaranya, keanekaragaman gender, latar belakang agama sosio-ekonomi dan etnik, serta kemampuan akademis.

Dalam penerapan pembelajaran kooperatif terdapat berbagai macam teknik yang bisa digunakan untuk melaksanakan pembelajaran kooperatif, diantaranya adalah makeamatch (mencari pasangan), bertukar pasanngan, berpikir berpasangan (think pair share), berkirim salam dan soal, kepala bernomor (number head), two stay two stray, inside-outside circle, jigsaw, paired storytelling, teams game tournament (tgt), dan students achievement division (stad). Dalam penelitian ini penulis menggunakan teknik make a match atau mencari pasangan, dimana dalam pembelajarannya menggunakan media kartu yang telah dipersiapkan sebelumnya.

\section{Cooperative Learning Type Make A Match}

Teknik belajar mengajar mencari pasangan (make a match) dikembangkan oleh Lorna Curran pada tahun 1994. "Salah satu keunggulan teknik ini adalah siswa mencari pasangan sambil belajar mengenai suatu konsep atau topik dalam suasana menyenangkan" (Lie, 2010: 55). Teknik ini dapat digunakan dalam semua mata pelajaran dan untuk semua tingkatan usia anak didik.

Hal-hal yang perlu dipersiapkan jika pembelajaran dikembangkan dengan teknik make a match adalah kartu-kartu. Kartu-kartu tersebut terdiri dari kartu berisi pertanyaan-pertanyaan dan kartu lainnya berisi jawaban-jawaban dari pertanyaan-pertanyaan tersebut yang sebelumnya telah dipersiapkan sesuai dengan topik yang akan dipelajari siswa. 
Langkah berikutnya adalah guru membagi komunitas kelas menjadi tiga kelompok. Kelompok pertama merupakan kelompok pembawa kartu-kartu berisi pertanyaanpertanyaan. Kelompok kedua adalah kelompok pembawa kartu-kartu berisi jawaban-jawaban. Kelompok ketiga adalah kelompok penilai. Pengaturan ruangan kelas menyesuaikan dengan pembelajaran yaitu berbentuk huruf $U$. Kelompok pertama dan kedua yang memegang kartu berisi pertanyaan dan jawaban berjajar saling berhadapan.

Jika masing-masing kelompok sudah berada diposisi yang telah ditentukan, maka guru memberikan instruksi sebagai tanda agar kelompok pertama maupun kelompok kedua saling bergerak mereka bertemu, mencari pasangan pertanyaanjawaban yang cocok. Berikan kesempatan kepada mereka untuk berdiskusi, Ketika mereka diskusi alangkah baiknya jika diiringi musik instrumentalia yang lembut. Hasil diskusi ditandai oleh pasanganpasangan antara anggota kelompok pembawa kartu pertanyaan dan anggota kelompok pembawa kartu jawaban.

Pasangan-pasangan yang sudah terbentuk wajib menunjukkan pertanyaanjawaban kepada kelompok penilai. Kelompok ini kemudian membaca apakah pasangan pertanyaan itu cocok. Setelah penilaian dilakukan, aturlah sedemikian rupa kelompok pertama dan kelompok kedua bersatu kemudian memposisikan diri menjadi kelompok penilai. Sementara kelompok penilai pada sesi pertama tersebut dipecah menjadi dua, sebagian anggota memegang kartu pertanyaan sebagian lainnya memegang kartu jawaban. Posisikan kembali dalam bentuk huruf U. Guru menginstruksikan kembali menandai kelompok pemegang kartu pertanyaan dan jawaban bergerak mencari, mencocokkan, dan mendiskusikan pertanyaan-jawaban. Berikutnya adalah masing-masing pasangan pertanyaanjawaban menunjukkan hasil kerjanya kepada kelompok penilai.
Perlu diketahui bahwa tidak semua siswa baik yang berperan sebagai pemegang kartu pertanyaan, pemegang kartu jawaban, maupun penilai mengetahui dan memahami secara pasti apakah betul kartu pertanyaan-jawaban yang mereka pasangakan sudah cocok. Demikian halnya bagi peserta didik kelompok penilai. Mereka juga belum mengetahui pasti apakah penilaian mereka benar atas pasangan-pasangan pertanyaan-jawaban. Berdasarkan kondisi tersebut guru memfasilitasi diskusi untuk memberikan kesempatan kepada seluruh siswa menginformasikan hal-hal yang mereka telah lakukan yaitu memasangkan pertanyaan-jawaban dan melaksanakan penilaian.

\section{Make A Match Dalam Pembelajaran Writing}

Salah satu cara untuk membuat kelas EYL lebih menarik adalah dengan penggunaan alat bantu mengajar atau media ketika guru mengajar. Media menurut Romiszowski (Suyanto, 2010: 100) adalah ' $\ldots$ any extension of man which allows him to affect other people who are not in face to face with him. Thus, communication media include letters, television, film, printed matter and telephone' . Dalam pembelajaran make a match, peran media sangatlah sentral karena fungsi media juga sebagai bahan ajar. Media yang digunakan dalam pembelajaran make a match adalah kartukartu yang berisi pertanyaan yang disertai gambar serta kartu-kartu yang berisi jawaban. Kartu-kartu tersebut berisi mengenai topik yang akan dipelajari siswa selama pembelajaran. Berikut adalah langkah-langkah pembelajaran writing menggunakan teknik make a match:

a. Guru menyiapkan beberapa kartu yang berisi beberapa konsep atau topik yang cocok untuk sesi review, satu bagian kartu soal atau pertanyaan dan bagian lainnya kartu jawaban. 
b. Guru membagi komunitas siswa kedalam 3 kelompok yaitu kelompok pemegang kartu pertanyaan, kelompok pemegang kartu jawaban, dan kelompok penilai.

c. Guru menjelaskan aturan dalam pelaksanaan kegiatan make a match

d. Guru membagikan kartu-kartu kepada kelompok pemegang kartu pertanyaan dan kelompok pemegang kartu jawaban secara acak.

e. Tiap siswa menerima dan memikirkan pertanyaan/jawaban dari kartu yang dipegang.

f. Guru menginstruksikan siswa untuk mencari kartu pasangannya yang cocok dengan tenggat waktu yang sudah ditentukan.

g. Setiap siswa mencari pasangan kartu yang cocok dengan kartunya.

h. Siswa yang sudah menemukan kartu pasangannya melaporkan kepada kelompok penilai untuk diberikan poin.

i. Setiap siswa yang dapat mencocokkan kartunya sebelum batas waktu diberi poin.

j. Jika siswa tidak dapat mencocokkan kartunya dengan kartu temannya (tidak dapat menemukan kartu soal atau kartu jawaban) akan mendapatkan hukuman, yang telah disepakati bersama.

k. Siswa kemudian duduk sesuai dengan pasangannya, kemudian secara bergantian menyampaikan hasil pekerjaannya sesuai instruksi guru.

1. Setelah satu babak, kartu dikocok lagi agar tiap siswa mendapat kartu yang berbeda dari sebelumnya dan kelompok pemegang kartu pertanyaan dan jawaban bertukar tempat dengan kelompok penilai, demikian seterusnya.

m. Siswa juga bisa bergabung dengan 2 atau 3 siswa lainnya yang memegang kartu yang cocok.

n. Guru bersama-sama dengan siswa membuat kesimpulan terhadap materi pelajaran.

\section{Metode Penelitian}

Penelitian yang akan digunakan berfokus pada masalah proses belajar dan hasil belajar dengan menggunakan pendekatan kooperatif tipe make a match. Jenis penelitian yang akan digunakan tergolong pada penelitian kelas (classroom research) dengan bentuk khusus penelitian tindakan yang dilakukan di kelas, dan lazim disebut penelitian tindakan kelas (classroom action research).Alasan penulis menggunakan desain Penelitian Tindakan Kelas dalam penelitian ini yaitu karena adanya kesamaan karakteristik yang terdapat dalam PTK dengan masalah yang ada. Adapun masalah yang diteliti yaitu mengenai kemampuan writing siswa dalam pembelajaran bahasa Inggris di Sekolah Dasar, karena untuk memperoleh kemampuan writing yang baik dalam pembelajaran bahasa Inggris harus dilakukan secara bertahap sama halnya dengan PTK.Penelitian dilakukan di SD Negeri Cikoneng yang berada di Kecamatan Cileunyi Kabupaten Bandung, khususnya di kelas V. Subyek penelitian adalah siswa sekolah dasar kelas V sebanyak 25 orang, yang terdiri dari 12 orang perempuan dan 13 orang lakilaki.Adapun pertimbangan alasan pemilihan subjek adalahberdasarkan hasil wawancara dengan guru kelas $\mathrm{V}$ dan guru yang mengajar bahasa Inggris di kelas tersebut, serta observasi pembelajaran.

\section{Instrumen Penelitian}

Untuk memperoleh data yang akurat dalam penelitian, diperlukan alat pengumpulan data yang tepat dengan permasalahan pada penelitian ini, yaitu sebagai berikut:

1. Lembar Observasi

Lembar observasi adalah alat penelitian yang banyak digunakan untuk mengukur tingkah laku individu atau proses terjadinya suatu kegiatan yang dapat diamati. Lembar observasi digunakan peneliti untuk mengumpulkan data berupa aktivitas 
siswa selama pembelajaran writing dengan make a match berlangsung

2. Lembar Wawancara

Lembar wawancara adalah daftar pertanyaan yang sudah dipersiapkan peneliti untuk mengetahui sesuatu yang berhubungan dengan penelitian. Dalam penelitian ini, peneliti mewawancarai beberapa perwakilan siswa dari setiap tingkatan yaitu pandai, sedang, dan kurang. Wawancara ini bermaksud untuk mengetahui kesulitan-kesulitan yang di alami siswa dalam pembelajaran writing dengan menggunakan make a match.

3. Catatan Lapangan

Catatan lapangan adalah catatan yang digunakan untuk mencatat kejadiankejadian yang muncul dalam aktiviitas pembelajaran writing yang terjadi diluar rencana yang dapat mempengaruhi pembelajaran.

4. Lembar Kerja Siswa

Lembar kerja Siswa (LKS) adalah berupa panduan yang disajikan melalui permasalahan yang mengarahkan siswa untuk menemukan sendiri konsep yang dipelajarinya.

5. Alat Evaluasi

Alat evaluasi yang dipergunakan pada tindakan dua dalam setiap siklusnya, berupa worksheet individu. Worksheet individu merupakan instrumen yang dipergunakan untuk mengumpulkan sejumlah data mengenai daya serap dan tingkat keberhasilan terhadap materi pembelajaran yang telah diberikan, sehingga dapat mengukur tingkat keberhasilan guru dalam mengajar.

\section{Hasil dan Pembahasan \\ Siklus I}

Pada pelaksanaan siklus I penggunaan make a match pada pembelajaran writing dengan tema time masih belum optimal.Hal ini terlihat dari aktivitas siswa pada saat pembelajaran masih sulit untuk dikondisikan, banyak siswa yang belum memahami peraturan kegiatan make a match. Penyebabnya adalah karena siswa masih merasa kaku dengan pembelajaran writing yang menggunakan make a match.

Make a match merupakan cara pembelajaran baru yang dilaksanakan di kelas V sekolah dasar, ini karena siswa masih terbiasa menggunakan metode pembelajaran klasikal atau konvensional, dimana guru menjelaskan materi kemudian memberikan tugas berupa writing skill tanpa mengembangkan kemampuan sosial mereka padahal writing merupakan aktivitas yang cukup kompleks dimana memerlukan latihan secara berkesinambungan dan bantuan pemahaman dari teman sebaya sehingga dibutuhkan pula kemampuan sosial yang baik. Bagi penelitipun hal ini merupakan pengalaman pertama dalam menggunakan make a matchpada pembelajaran writing. Peneliti juga harus mampu mengelola kelas sehingga pembelajaran writing dengan menggunakan make a match dapat berlangsung seoptimal mungkin. Hal ini tampak pada saat pembelajarankegiatan make a match berlangsung sebagian besar siswa belum terkondisikan dengan baik sehingga suasana kelas kurang begitu kondusif walaupun siswa tampak sangat antusias dalam melaksanakan kegiatan.

Aktivitas siswa dalam melakukan kegiatan make a match sudah cukup baik, siswa tampak cukup antusias dalam melaksanakan kegiatan make a match. Akan tetapi, banyak siswa yang belum memahami instruksi yang diberikan guru sehingga masih ada siswa yang berkalikali bertanya pada guru dan salah dalam mencocokkan pasangan kartu. Hal ini tampak pada penilaian proses make a match, dari jumlah siswa sebanyak 25 terdapat $11(44 \%)$ siswa mendapat kriteria penilaian baik, 11 (44\%) siswa mendapat kriteria penilaian cukup dan 3 siswa (12\%) mendapat kriteria penilaian kurang.Selain itupada saat kegiatan pembelajaran masih 
banyak siswa yang membutuhkan pengarahan.

Hasil belajar siswa berdasarkan KKM mata pelajaran bahasa Inggris yang ditetapkan sekolah dengan nilai berkisar 55 sudah cukup baik, karena nilai rata-rata hasil belajar siswa sudah mencapai 57,5. Akan tetapi jika dilihat berdasarkan kriteria ketuntasan belajar (mastery learning) yang mencapai 75 dapat dikatakan belum memenuhi standar. Apabila dilihat secara perorangan delapan (32\%) siswa yang mendapatkan nilai di atas standar mastery learning, sedangkan $17(68 \%)$ siswa berada dibawah nilai standar mastery learning.

\section{Siklus II}

Pada siklus II penggunaan make a match pada pembelajaran writing menunjukkan peningkatan yang cukup baik. Pada siklus II peneliti berusaha memperbaiki kekurangan-kekurangan pada pembelajaran sebelumnya, agar tujuan pembelajaran dapat tercapai serta dapat meningkatkan pemahaman siswa tentang konsep pembelajaran writing dengan menggunakanmake a match. Peneliti juga mulai dapat mengelola kelas dengan baik dan memberikan arahanarahan pada siswa dalam pembelajaran. Pada saat pembelajaran terlihat keadaan kelas mulai dapat dikondisikan. Selain itu penjelasan dan instruksi peneliti mulai dapat dipahami oleh siswa.

Aktivitas siswa juga mulai memperlihatkan kemajuan pada saat kegiatanmake a matchberlangsung. Instruksi yang diberikan peneliti sudah cukup baik dilaksanakanoleh siswa. Dalam mencari pasangan kartu siswa dapat berinteraksi dengan teman sebayanya untuk menemukan pasangan kartunya sehingga tampak kemampuan sosial dapat berkembang cukup baik. Hal ini tampak pada penilaian proses make a match, dari jumlah siswa sebanyak 25 terdapat 17 (68\%) siswa mendapat kriteria penilaian baik, 15 (20\%) siswa mendapat kriteria penilaian cukup dan 3 siswa (12\%) mendapat kriteria penilaian kurang.

Hasil belajar siswa berdasarkan KKM mata pelajaran bahasa Inggris yang ditetapkan sekolah dengan nilai berkisar 55 sudah cukup baik, karena nilai rata-rata hasil belajar siswa sudah mencapai 63,6. Akan tetapi jika dilihat berdasarkan kriteria ketuntasan belajar (mastery learning) yang mencapai 75 dapat dikatakan belum memenuhi standar mastery learning. Apabila dilihat secara perorangan sembilan (36\%) siswa yang mendapatkan nilai di atas standar mastery learning, sedangkan 16 (64\%) siswa berada dibawah nilai standar mastery learning.

\section{Siklus III}

Pada siklus III penggunaan make a match pada pembelajaran writing menunjukkan peningkatan yang cukup signifikan.Terpeliharanya kondisi belajar siswa memberikan dampak yang baik terhadap hasil belajar, Antusias siswa pada pembelajaran writing dengan menggunakan make a matchsangat tinggi, ini terlihat dari respon mereka pada saat menjawab pertanyaan peneliti.

Pada siklus III ini siswa sudah dapat menginterpretasikan diri mereka dengan cukup baik dalam mengembangkan kemampuan sosialnya. Hal ini tampak dengan komunikasi yang sangat baik antara teman dalam mencari pasangan kartu saat kegiatan make a match. Berdasarkan dari gambaran kegiatan proses pembelajaran dan aktifitas siswa tersebut, maka hasil kegiatan writing dengan make a matchpada siklus III ternyata menunjukkan peningkatan yang cukup baik. Hal ini tampak pada penilaian proses make a match, dari jumlah siswa sebanyak 25 terdapat $19(76 \%)$ siswa mendapat kriteria penilaian baik, enam (24\%) siswa mendapat kriteria penilaian cukup dan tidak ada siswa (0\%) mendapat kriteria penilaian kurang. Dengan 
demikian aktivitas siswa selama proses pembelajaran dari siklus I sampai siklus III mengalami peningkatan.

Make a match merupakan teknik yang menekankan pada proses bukan hasil semata. Dalam pembelajarannya dibutuhkan kerjasama antara sesama siswa jadi tidak hanya bergantung pada satu orang saja. Hal tersebut sesuai dengan tiga konsep sentral yang dikemukakan oleh Slavin (Isjoni, 2000: 21) yaitu 'Penghargaan kelompok, pertanggungjawaban individu, dan kesempatan yang sama untuk berhasil'. Oleh karena itu dalam kegiatan writing menggunakan make a match adanya penghargaan, pertanggungjawaban dan kesempatan yang sama untuk berhasil. Dengan pengelolaan yang baik terhadap ketiga konsep sentral tersebut yang didalamnya termasuk kepada pengelolaan kelas yang lebih baik yang dilakukan oleh guru dalam tiap siklusnya dapat membantu siswa meningkatkan proses dan hasil belajar siswa.

\section{Simpulan dan Saran}

Proses pembelajaran writing dengan menggunakan make a match yaitu siswa mencari pasangan kartu jawaban dan pertanyaan yang cocok. Hal-hal yang perlu dipersiapkan jika pembelajaran dikembangkan dengan teknik make a match adalah kartu-kartu. Kartu-kartu tersebut terdiri dari kartu berisi pertanyaan-pertanyaan dan kartu lainnya berisi jawaban-jawaban dari pertanyaanpertanyaan tersebut yang sebelumnya telah dipersiapkan sesuai dengan topik yang akan dipelajari siswa.Penggunaanmake $a$ match pada pembelajaran writing telah memperlihatkan perubahan proses belajar pada setiap siklusnya. Hal ini terlihat dari peningkatan proses pembelajaran pada siklus II dengan kriteria baik meningkat menjadi $68 \%$ yang sebelumnya pada siklus I hanya $44 \%$ serta siklus III dengan kriteria baik meningkat menjadi $76 \%$. Penerapanmake a match telah memberikan hasil positif dengan menciptakan suasana belajar yang interaktif dan bermakna bagi siswa.

Hasil belajar siswa dalam pembelajaran writing di kelas V SD dengan menggunakan make a match sudah cukup baik, karena nilai rata-rata hasil belajar siswa sudah mencapai 57,5. Tetapi jika dilihat secara perorangan delapan (32\%) siswa yang mendapatkan nilai di atas standar mastery learning, 17 (68\%) siswa masih di bawah standar mastery learning. Sedangkan pada siklus II hasil pembelajaran siswa dalam writing dengan menggunakan make a match mengalami peningkatan dari siklus I. Hal ini dibuktikan dengan nilai rata-rata hasil belajar siswa mencapai 63,6. Jika dilihat secara perorangan sembilan $(36 \%)$ siswa yang mendapatkan nilai di atas standar mastery learning, 16 (64\%) siswa berada di bawah mastery learning, dan pada siklus III hasil belajar siswa mengalami peningkatan dari siklus II, hal ini dapat dilihat dari nilai rata-rata hasil belajar siswa mencapai 77,2 . Jika dilihat secara perorangan $15 \quad(60 \%)$ siswa sudah mendapatkan nilai di atas standar mastery learning dan $10(40 \%)$ siswa berada di bawah standar mastery learning.

Hasil penelitian ini dapat dijadikan evaluasi dan introspeksi oleh guru maupun kepala sekolah mengenai kegiatan pembelajaran yang telah dilakukan. Hasil penelitian ini diharapkan dapat memberikan masukan kepada guru-guru SD, Khususnya guru bahasa Inggris SD tentang pembelajaran bahasa Inggris di kelas V SD, hal ini dimaksudkan untuk memperbaiki kekurangan yang ada dalam pembelajaran dan memberikan suatu masukan atau gagasan untuk peningkatan ke arah yang lebih baik.

\section{Daftar Pustaka}

Aqib, dkk.(2006).Penelitian Tindakan Kelas. Bandung: Yrama Widya. 
Byrne, D. (1995). Teaching Writing Skills. UK: Longman.

Brewster, J and Gail Ellis. (2001). The primary English teacher Guide. England: Pearson Educational Limited.

Isjoni. (2009). Cooperative Learning. Bandung: Alfabeta.

Lie, A. (2010). Mempraktikkan Cooperative Learning di Ruangruang Kelas. Jakarta: Grasindo.

Linse, C. T. (2005). Practical English Language Teaching Young Learners. New York: McGraw Hill.

Moleong, J. M. (2007). Metodologi Penelitian Kualitatif. Bandung: PT. Remaja Rosda Karya.

Sadulloh, U, dkk. (2007). Pedagogik. Bandung: Citra Utama.

Sutardi, D. dan Sudirjo, E. (2007). Pembaharuan Dalam PBM di $S D$. Bandung: UPI Press.

Suyanto, K. K. E. (2010). English for Young Learners. Jakarta: Bumi Aksara.

Tarigan, H. G. (1994). Menulis Sebagai Suatu Keterampilan Berbahasa. Bandung: Angkasa.

Yunus M, dkk. (2009). Menulis 1. Jakarta: Universitas Terbuka. 
